\title{
Length-Weight and Length-Length Relationships of Heterotis niloticus (Cuvier, 1829) and Raiamas senegalensis (Steindachner, 1870)
}

\section{Olanrewaju AN ${ }^{1 *}$, Kareem $\mathrm{OK}^{2}$, Nyaku $\mathrm{RE}^{3}$ and Tubo $\mathrm{MT}^{1}$}

${ }^{1}$ Federal College of Freshwater Fisheries Technology, Maiduguri, Nigeria

${ }^{2}$ Department of Aquaculture and Fisheries Management, University of Ibadan, Nigeria

${ }^{3}$ National Institute for Freshwater Fisheries Research, Zonal Office Maiduguri, Nigeria

\begin{abstract}
The sustainable exploitation of freshwater fish species of commercial value is inevitable for fishery to continuously play its role in the social and economic growth of Nigeria. Heterotis niloticus and Raiamas senegalensis are two commercially available species in Lake Alau. The length-weight relationship (LWR) and length-length relationship (LLR) of these species were investigated to determine their growth patterns and state of wellbeing. Fish samples were collected from fishermen landings weekly for four months. The morphometric indices such as Total Length (TL), Standard Length (SL) and Body Weight (BW) were assessed using standard methods. A total of 1583 specimens comprising $602 \mathrm{H}$. niloticus $(51.61 \%$ males and $48.39 \%$ females $)$ and $981 R$. Senegalensis $(56.57 \%$ males and $43.43 \%$ females) were collected. TL ranged from 10.2 to $42.8 \mathrm{~cm} ; 15.5$ to $41.6 \mathrm{~cm}$, SL 9.5 to $39.9 \mathrm{~cm} ; 14.0$ to $39.9 \mathrm{~cm}$ and weighed between 128.50 and $420.14 \mathrm{~g} ; 123.05$ and $401.8 \mathrm{~cm}$ for $\mathrm{H}$. niloticus and $R$. senegalensis, respectively. The growth coefficient (b) ranged between 3.127 and 3.340 for $H$. niloticus and 2.592 and 3.193 for $R$. senegalensis This indicates positive allometric growth pattern for the two-species investigated. The LLR varied from 1.511 to 2.148 and 1.506 to 1.820 for $H$. niloticus and $R$. senegalensis, with mean condition factor of $2.04 \pm 1.76$ ( $H$. niloticus) and $1.97 \pm 1.98$ ( $R$. senegalensis). This study therefore concludes that Lake Alau is favourable to good growth, reproduction, and survival of these species.
\end{abstract}

Keywords: Growth patterns; Length-weight; Morphometric; Lake Alau

\section{Introduction}

Inland tropical water has rich biodiversity which plays significant role in the economy, culture, tradition and food habits of Nigerians. About 316 recorded freshwater bony fish species belonging to 50 families have been reported in Nigeria [1]. Heterotis niloticus and Raimas senegalensis constituted some of the most dominant fish species in these waterbodies. These fresh water species inhabit from muddy to clean water and may be found in lakes, streams, rivers, canals and ponds, occurring mainly in shallow waters. They are bottom and column feeders, feeding on aquatic algae and higher plants as well as insects, crustaceans and rotifers. Recently, there is a report of acute reduction in the number of these species in inland waters in Nigeria because of over-exploitation by indigenous fishers who destroy the habitat and fishery resources [2].

Length-weight and length-length relationships are used extensively in fishery research and management [3]. According to Akinsanya et al. [4], the emanating need to culture fishes for protein consumption for the rapidly growing population in Nigeria has made it necessary to intensify studies on the length frequency of the African freshwater fishes. It is equally necessary to provide and increase the knowledge of the stock available. The length-weight relationship is one of the standard methods that yield valid biological information. It establishes the mathematical relationship between the two variables (length and weight) so that the unknown variable can be readily computed from the known variable. Length and weight data are essential for estimating growth rates, age structure [5], for calculating the standing stocks biomass [6], condition indices [7] and several other aspects of fish population dynamics [8].

Length-length relationships (LLRs) are also important in fishery management for comparative growth studies [9]. Length-length relationships are still scarce for most tropical and sub-tropical fish species $[6,10,11]$, although LLRs are readily available for most European and North American freshwater and marine fishes [12-14]. The condition factor (CF) is an index reflecting interactions between biotic and abiotic factor on the physiological condition of fishes. It shows the welfare of the population during the various stages of the life cycle [15] Length-weight relationship (LWR) and length-length relationship (LLR) of fishes can indicate species status in an environment and characterize patterns of growth $[16,17]$. Despite the various studies on this subject for marine and freshwater fishes in Nigeria [18-29], there is paucity of information on length-weight relationships and lengthlength relationships of these commercially important fishes from Lake Alau. The present study therefore aims at providing scientific background on the LWR and LLR of Heterotis niloticus and Raimas senegalensis in Lake Alau, Nigeria.

\section{Materials and Methods}

\section{Description of the study site}

Lake Alau is situated en route of River Ngadda, along Bama road in Borno State, Nigeria. It is $22 \mathrm{Km}$ from Maiduguri lying at a Latitude: $11^{\circ} 44^{\prime}$ North, and at Longitude: $13^{\circ} 10^{\prime}$ East. The total area of the lake is about $56 \mathrm{Km}^{2}$ with a maximum depth of $9 \mathrm{~m}$. It has a distinct tropical savannah climate with a marked monsoonal effect with an

*Corresponding author: Olanrewaju AN, Federal College of Freshwater Fisheries Technology, P.M.B 1060, Maiduguri, Nigeria, Tel: (+234) 805222 1984; E-mail: arogidigbaonline@yahoo.com

Received December 16, 2016; Accepted January 20, 2017; Published January 23, 2017

Citation: Olanrewaju AN, Kareem OK, Nyaku RE, Tubo MT (2017) LengthWeight and Length-Length Relationships of Heterotis niloticus (Cuvier, 1829) and Raiamas senegalensis (Steindachner, 1870). J Aquac Res Development S2: 011. doi:10.4172/2155-9546.S2-011

Copyright: (C) 2017 Olanrewaju AN, et al. This is an open-access article distributed under the terms of the Creative Commons Attribution License, which permits unrestricted use, distribution, and reproduction in any medium, provided the original author and source are credited. 
Citation: Olanrewaju AN, Kareem OK, Nyaku RE, Tubo MT (2017) Length-Weight and Length-Length Relationships of Heterotis niloticus (Cuvier, 1829) and Raiamas senegalensis (Steindachner, 1870). J Aquac Res Development S2: 011. doi:10.4172/2155-9546.S2-011

Page 2 of 5

average rainfall of $600 \mathrm{~mm}$, humidity $49.0 \%$ and average atmospheric temperature ranging from a minimum of $28^{\circ} \mathrm{C}$ in wet season to a maximum of $48^{\circ} \mathrm{C}$ in dry season [30,31]. The reservoir is characterized with loamy soil and a total storage capacity of 54,600 ha. The reservoir is a means of livelihood to rural populations who live nearby especially from Maiduguri and Konduga town. A large number of fishes including some commercially important species are fished by both small and large scale fishers throughout the year.

\section{Sample collection and laboratory activities}

Regular weekly samples were obtained from fishermen's catch at their landing site during August 2015 to January 2016. All sampled fishes were identified to species level using standard keys $[1,32]$. Total specimens were brought to the Wet laboratory, National Institute for Freshwater Fisheries Research (NIFFR), Maiduguri Zonal Office for further analysis. After blotting the specimens to remove excess water, total length (TL) and standard length (SL) of each fish were measured and body weight (BW) determined following Kareem et al. [18]. The sex of each specimen was identified by examination of the gonads.

\section{Determination of length-weight and length-length relationships}

The relationship between the length and the weight of the fish

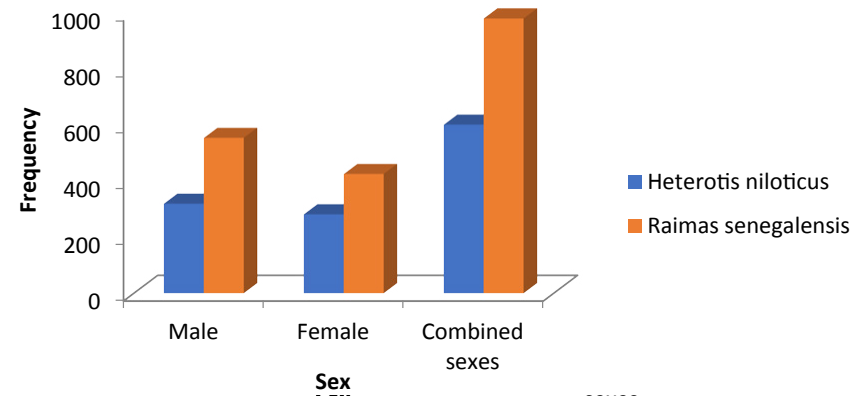

Figure 1: Sample size and composition of Heterotis niloticus and Raimas senegalensis collected from Lake Alau. was estimated using the equation $\mathrm{W}=\mathrm{aL}^{\mathrm{b}}$ [33] and logarithmically transformed into $\log W=\log a+b \log L$ Where; $\mathrm{W}$ is the weight of the fish, $\mathrm{L}$ is the total length of the fish, $a$ is the constant or intercept and $b$ is the length exponent or slope. The determination coefficient $\left(\mathrm{r}^{2}\right)$ was used as an indicator of the quality of the linear regression [34]. The null hypothesis that $\mathrm{b}=3$ was tested using two tailed $\mathrm{t}$ test as described by Zar [35]. The t-test analysis was carried out for the length and weight data of each species to confirm the significance of the relationship at $\mathrm{P}<0.05$ [34]. The length-length relationship (LLR) was estimated as $\mathrm{T} L$ $=\mathrm{aS} L^{b}$ and its $\log -\log$ form $\log (T L)=\log (a)+b \log (S L)$. Goodness of fit was determined using the coefficient of determination $\left(\mathrm{r}^{2}\right)$ and the null hypothesis that $\mathrm{b}=1$ was tested using two tailed $\mathrm{t}$ test.

\section{Statistical analysis}

All the statistical analyses were considered at significance level of 5\% $(\mathrm{p}<0.05)$. The Statistical Package for Social Sciences (SPSS, version 17) and Microsoft Office Excel software were deployed in this study. Tables and graphs were plotted with the use of MS Words and Excel 2007.

\section{Results and Discussion}

The sample size and sex distribution for the two-species investigated are shown in Figure 1. A total of 1583 specimens comprise of Six hundred and two (602) Heterotis niloticus and Nine hundred and eighty-one (981) Raimas senegalensis were collected and used for the length-weight and length- length relationship calculations. In $H$. niloticus, 320 (51.61\%) were males and 282 (48.39\%) were females while R. Senegalensis consists of 555 (56.57\%) males and 426 (43.43\%) females. The observed sex distribution among the species showed preponderance of males over females in their population. The sex ratio recorded in this study is in compliance with the works of Achakzai et al. [36] in Manchar Lake, Kashyap et al. [37] in Gomti River and Lawal et al. [38] in Epe Lagoon.

The result of the length-weight analysis for $H$. niloticus and $R$. senegalensis collected from Lake Alau was presented in Tables 1 and 2. The standard and total length range for H. niloticus is 9.50 to 39.90 $\mathrm{cm}$ and 10.20 to $42.80 \mathrm{~cm}$, respectively. The mean standard length

\begin{tabular}{|c|c|c|c|c|c|c|}
\hline \multirow{2}{*}{ Sex } & \multicolumn{3}{|c|}{ Total length $(\mathrm{cm})$} & \multicolumn{3}{|c|}{ Standard length $(\mathrm{cm})$} \\
\hline & Minimum & Maximum & Mean \pm SD & Minimum & Maximum & Mean \pm SD \\
\hline \multicolumn{7}{|c|}{ H. niloticus } \\
\hline Male & 19.80 & 42.80 & $27.21 \pm 5.06$ & 16.80 & 39.90 & $25.79 \pm 5.21$ \\
\hline Female & 10.20 & 38.10 & $26.74 \pm 4.96$ & 9.50 & 36.50 & $25.39 \pm 4.81$ \\
\hline Combined sex & 10.20 & 42.80 & $26.99 \pm 5.01$ & 9.50 & 39.90 & $25.61 \pm 5.03$ \\
\hline \multicolumn{7}{|c|}{ R. senegalensis } \\
\hline Male & 17.80 & 38.20 & $28.56 \pm 4.88$ & 16.50 & 36.50 & $26.15 \pm 4.88$ \\
\hline Female & 15.50 & 41.60 & $27.02 \pm 4.70$ & 14.0 & 39.90 & $25.57 \pm 4.71$ \\
\hline Combined sex & 15.50 & 41.60 & $27.32 \pm 4.81$ & 14.00 & 39.90 & $25.90 \pm 4.81$ \\
\hline
\end{tabular}

$\mathrm{SD}=$ Standard deviation, $\mathrm{cm}=$ centimeter

Table 1: Total length and standard length distribution of Heterotis niloticus collected from Lake Alau.

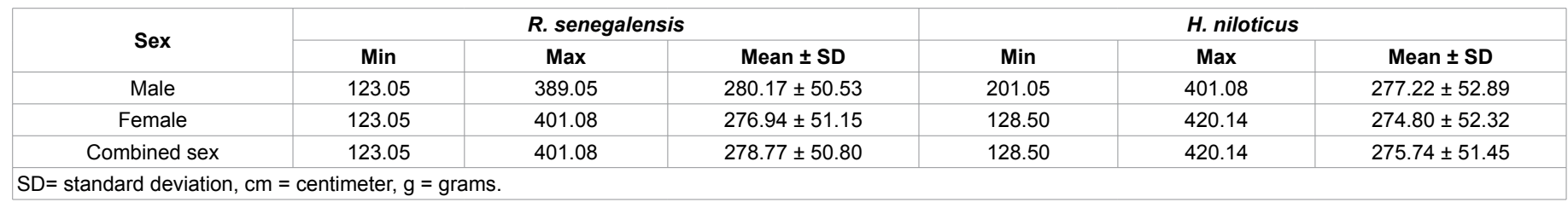

Table 2: Weight distribution of $R$. senegalensis and $H$. niloticus collected from Lake Alau. 
Citation: Olanrewaju AN, Kareem OK, Nyaku RE, Tubo MT (2017) Length-Weight and Length-Length Relationships of Heterotis niloticus (Cuvier, 1829) and Raiamas senegalensis (Steindachner, 1870). J Aquac Res Development S2: 011. doi:10.4172/2155-9546.S2-011

Page 3 of 5

\begin{tabular}{|l|c|c|c|c|}
\hline Sex & a & b & sb & $\mathbf{r}^{\mathbf{2}}$ \\
\hline Male & 0.830 & 3.340 & 0.161 & 0.774 \\
\hline Female & 0.752 & 3.127 & 0.430 & 0.851 \\
\hline Combined sexes & 0.798 & 3.205 & 0.736 & 0.702 \\
\hline \multicolumn{4}{|c|}{ R. senegalensis } \\
\hline Male & 0.534 & 3.193 & 0.183 & 0.827 \\
\hline Female & 0.682 & 2.592 & 0.252 & 0.771 \\
\hline Combined sexes & 0.625 & 2.829 & 0.150 & 0.802 \\
\hline
\end{tabular}

$\mathrm{a}=$ intercept, $\mathrm{b}=$ slope, $\mathrm{sb}=$ standard error of the slope, $\mathrm{r}^{2}=$ correlation coefficient.

Table 3: Regression coefficient for length-weight relationships of $H$. niloticus and R. senegalensis collected from Lake Alau.

\begin{tabular}{|c|c|c|c|c|}
\hline Sex & a & b & sb & $\mathbf{r}^{2}$ \\
\hline \multicolumn{5}{|c|}{$\boldsymbol{H}$. niloticus } \\
\hline Male & 0.525 & 2.148 & 0.017 & 0.790 \\
\hline Female & 0.774 & 1.511 & 0.011 & 0.881 \\
\hline Combined sexes & 0.601 & 1.802 & 0.010 & 0.813 \\
\hline \multicolumn{5}{|c|}{$\boldsymbol{R}$. senegalensis } \\
\hline Male & 0.481 & 1.506 & 0.224 & 0.406 \\
\hline Female & 0.675 & 1.820 & 0.270 & 0.354 \\
\hline Combined sexes & 0.578 & 1.697 & 0.007 & 0.385 \\
\hline $\mathrm{a}=$ intercept, $\mathrm{b}=$ slope, $\mathrm{sb}=$ standard error of the slope, $\mathrm{r}^{2}=$ correlation coefficient.
\end{tabular}

Table 4: Length-length relationships (LLR) between total length (TL) and standard length (SL) of $H$. niloticus and $R$. senegalensis.

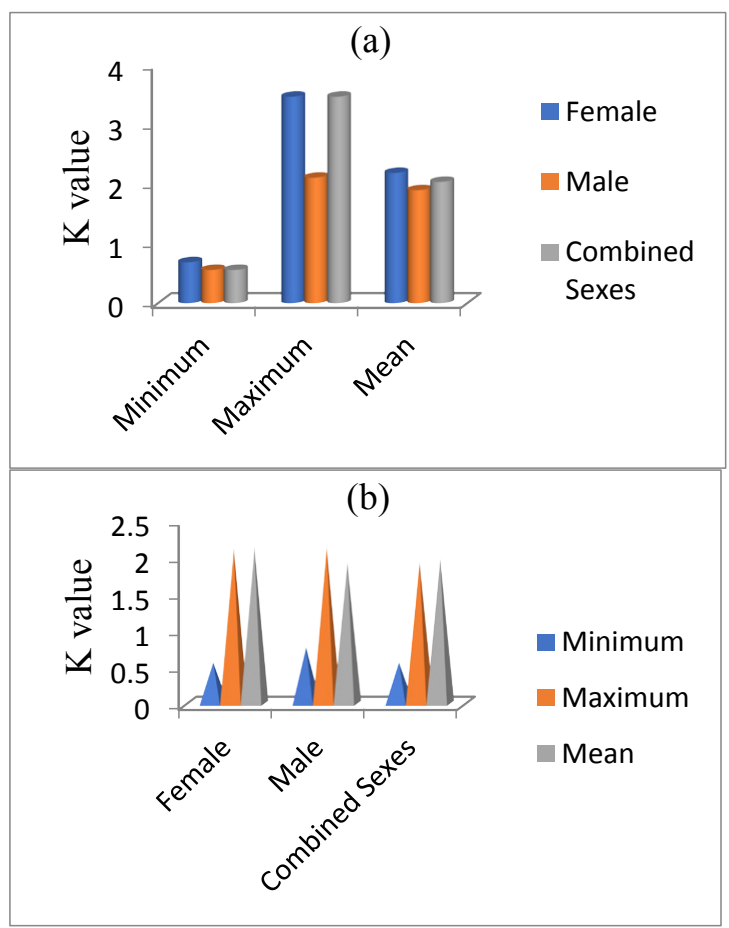

Figure 2: Condition factor of (a) $H$. niloticus and (b) $R$. senegalensis in Lake Alau.

ranged from $25.39 \pm 4.81 \mathrm{~cm}$ to $25.79 \pm 5.21 \mathrm{~cm}$ while total length varied between $26.74 \pm 4.96 \mathrm{~cm}$ and $27.21 \pm 5.06 \mathrm{~cm}$. However, the weight varied between $128.50 \mathrm{~g}$ to $420.14 \mathrm{~g}$ with mean varying from $274.80 \pm 52.32 \mathrm{~g}$ to $277.22 \pm 52.89 \mathrm{~g}$. This result showed that males were longer but females were heavier in $H$. niloticus population. This is in conformity with Le Cren [39] who reported that females are heavier than males of the same length probably because of differences in fatness and gonadal development.

Also in $R$. senegalensis, the standard length ranged from 16.5 to $36.5 \mathrm{~cm}$ for males and 14.0 to $39.90 \mathrm{~cm}$ for females while total length varied from 17.80 to $38.20 \mathrm{~cm}$ for males and 15.50 to $41.60 \mathrm{~cm}$. However, the mean standard and total lengths were between $25.57 \pm$ $4.71-26.15 \pm 4.88 \mathrm{~cm}$ and $27.02 \pm 4.70-28.56 \pm 4.88 \mathrm{~cm}$. The observed maximum body weight was $401.08 \mathrm{~g}$, for a female and minimum of $123.05 \mathrm{~g}$ whereas; the mean body weights were between $276.94 \pm 51.15$ $\mathrm{g}$ in females and $280.17 \pm 50.53 \mathrm{~g}$ in males.

The estimates of the regression parameters for males, females, and combined sexes of $H$. niloticus and $R$. Senegalensis are given in Table 3. The ' $a$ ' values obtained for $H$. niloticus is 0.830 for males, 0.752 for females and 0.798 for combined sexes. The regression coefficients $(b)$ values ranged from 3.340 for males, 3.127 for females to 3.205 for combined sexes. The result of calculated ' $b$ ' value indicated positive allometric growth in both sexes of $H$. niloticus $(b>3.0)$, which indicates that the fish grow as the cube of length. However, the relationship was highly significant $(\mathrm{P}<0.01)$ with coefficient of determination $\left(\mathrm{r}^{2}\right)$ ranged from 0.774 for male to 0.851 for female.

The intercept (a) values for $R$. senegalensis were 0.534 (male), 0.682 (female) and 0.625 (Combined sexes). The corresponding exponent ' $b$ ' values were $3.193,2.592$ and 2.829 for male, female and combined sexes, respectively. The exponent ' $b$ ' value of male gave a positive allometric growth while female and combined sexes exhibited negative allometric growth pattern.

The highest ' $b$ ' value attained in female $R$. senegalensis implies that the females gain weight at a faster rate in relation to its length. The correlation coefficients values which ranged between 0.771 and 0.802 showed a high degree of positive correlation between the standard length and body weight. Similar findings in Chrysichthys nigrodigitatus were reported by Abowei and Ezekiel [40] from Amassoma river flood plains Nigeria, where the positive allometry was evident. Ezekiel and Abowei [19] also reported positive allometric growth in Hepsetus odoe from Bangladesh with b value 2.768 (males) and 2.667 (females). Shafi and Yousuf [41] reported positive allometric growth for males (3.07) and negative allometric for females (2.77) in Schizothorax niger from Dal lake. In contrast, Kashyap et al. [37] reported allometric growth for males and females from India with $b$ value 2.95 (males) and 3.13 (females).

The regression analysis for length-length relationships (LLR) of $H$. niloticus and $R$. senegalensis is shown in Table 4 . The regression coefficients $(b)$ values for $H$. niloticus ranged from 1.511 (females) to 2.148 (males), whereas the ' $a$ ' values ranged from 0.525 to 0.774 for males and females respectively. The determination coefficient $\left(\mathrm{r}^{2}\right)$ values varied from 0.790 in males to 0.881 in females. Similarly, the calculated linear regression for $R$. senegalensis indicates significant differences between the slopes of the L-L relationship within sexes. The regression coefficient $b$ values varied between 1.506 for males and 1.820 for females. Hence, this result suggests that the species shows nonisometric growth pattern. However, the correlation coefficients for the species ranged from 0.354 in females to 0.406 in males. This is a clear indication that a weak correlation exist between the standard length and the total length of $R$. senegalensis from Lake Alau. The correlation of LLRs in the present study is similar to the findings of Adeyemi [42] for Synodontis resupinatus and Adeyemi [43] for Synodontis robbianus in the Idah, River Niger.

The condition factors $(\mathrm{K})$ of these species ranged between 0.56 and 3.47 (Figure 2). A closer examination of the condition factors 
Citation: Olanrewaju AN, Kareem OK, Nyaku RE, Tubo MT (2017) Length-Weight and Length-Length Relationships of Heterotis niloticus (Cuvier, 1829) and Raiamas senegalensis (Steindachner, 1870). J Aquac Res Development S2: 011. doi:10.4172/2155-9546.S2-011

revealed that females $H$. niloticus had the highest (3.47), followed by males $R$. senegalensis (2.14). The mean condition factor for both species (combined sexes) was $2.04 \pm 1.76$ (H. niloticus) and $1.97 \pm 1.98$ ( $R$. senegalensis) $[44,45]$. The results indicate that fish species are doing well in the lake. This result was higher than the mean value (0.98) reported for Heterotis niloticus in Amassoma flood plain, Niger Delta, Nigeria by Ezekiel and Abowei [21]. It can be concluded that $H$. niloticus and $R$. senegalensis gain weight at a faster rate in relation to their length, an indication of good environmental condition.

\section{Conclusion}

In conclusion, this study has provided some basic information on the length-weight and length-weight relationships for Heterotis niloticus and Raimas senegalensis that will be helpful in similar studies. $H$. niloticus and $R$. senegalensis exhibited different growth patterns, and showed a strong association between length and weight. As no information on this subject currently exists about Lake Alau, the present results may contribute to this invaluable database. Further, it would be useful for fishery biologists and managers to impose adequate regulations for sustainable fishery management in this Lake.

\section{References}

1. Olaosebikan BD, Raji A (2013) Field guide to Nigerian freshwater fishes (Revised Edition). National Institute of Freshwater Fisheries Research (NIFFR), New Bussa, Nigeria.

2. Mustapha MK (2010) Heterotis niloticus (Cuvier, 1829), A threatened fish species in Oyun Reservoir, Offa, Nigeria: The need for its conservation. Asian J Exp Biol Sci 1: 1-7.

3. Wang T, Wang HS, Sun GW, Huang D, Shen JH (2012) Length-weight and length-length relationships for some Yangtze River fishes in Tian-e-zhou Oxbow, China. J Appl Ichthyol 28: 660-662.

4. Akinsanya B, Otubanjo OA, Ibidapo CA (2007) Helminth bioload and length frequency distribution of Chrysichthys nigrodigitatus (Lacepede 1802) from Lekki Lagoon Lagos, Nigeria. Turkish Journal of Fisheries and Aquatic Sciences 7: 83-87.

5. Kohler N, Casey J, Turner P (1995) Length-weight relationships for 13 species of sharks from the western North Atlantic. Fish Bull 93: 412-418.

6. Martin-Smith KM (1996) Length/weight relationships of fishes in a diverse tropical fresh-water community, Sabah, Malaysia. Journal of Fish Biology 49: 731-734

7. Safran $P$ (1992) Theoretical analysis of the weight-length relationships in the juveniles. Mar Biol 112: 545-551.

8. Morato T, Afonso P, Lourinho P, Barreiros JP, Santos RS, et al. (2001) Lengthweight relationships for 21 coastal fish species of the Azores, North-eastern Atlantic. Fisheries Research 50: 297-302.

9. Moutopoulos DK, Stergiou KI (2002) Length-weight and length-length relationships of fish species from Aegean Sea (Greece). J Appl Ichthyol 18: 200-203.

10. Harrison TD (2001) Length-weight relationships of fishes from South African estuaries. Journal of Applied Ichthyology 17: 46-48

11. Ecoutin JM, Albaret JJ, Trape S (2005) Length-weight relationships for fish populations of relatively undisturbed tropical estuary: the Gambia. Fisheries Research 72: 347-351.

12. Sinovcic G, Franicevic M, Zorica B, Ciles-Kec V (2004) Length-weight and length-length relationships for 10 pelagic fish species from the Adriatic Sea (Crotia). J Applied Ichthyology 20: 156-158.

13. Leunda PM, Oscoz J, Miranda R (2006) Length-weight relationshipsof fishes from tributaries of the Ebro River, Spain. J Appl Ichthyol 22: 299-300.

14. Miranda R, Oscoz J, Leunda PM, Escala MC (2006) Weight-length of cyprinid fishes of the Iberian Peninsula. J Appl Ichthyol 22: 297-298.

15. Angelescu V, Gneri FS, Nani A (1958) La merluzadel mar argentino (biologia e taxonomia). Secr Mar Serv Hidrog Nav Publico H1004: 1-224.
16. Froese $R$ (2006) Cube law, condition factor and weight-length relationships: History, meta-analysis and recommendations. J Applied Ichthyol 22: 241-253.

17. Kharat SS, Khillare YK, Dahanukar N (2008) Allometric scaling in growth and reproduction of a freshwater loach Nemacheilus mooreh (Sykes). Electronic Journal of Ichthyology 4: 8-17.

18. Kareem OK, Olanrewaju AN, Orisasona O (2015) Length-weight relationship and condition factor of Chrysichythys nigrodigitatus and Schilbe mystus in Erelu Lake, Oyo State, Nigeria. Journal of Fisheries and Livestock Production 3: 149.

19. Ezekiel EN, Abowei JFN (2014) A study of length-weight relationship and condition factor of Hepsetus odoe (Bloch, 1794) from Amassoma flood plains. Ann Bio Sci 2: 10-17.

20. Dan-Kishiya AS (2013) Length-weight relationship and condition factor of five fish species from a tropical water supply reservoir in Abuja, Nigeria. American Journal of Research Communication 1: 175-187.

21. Ezekiel EN, Abowei JFN (2013) Length-weight relationship and condition factor of Heterotis niloticus from Amassoma flood plain, Niger Delta, Nigeria. App Sci Report 4: 164-172.

22. Ikongbeh OA, Ogbe FG, Solomon SG (2012) Length-weight relationship and condition factor of Bagrus docmac from Lake Akata, Benue state, Nigeria. Journal of Animal and Plant Sciences 15: 2267-2274.

23. Ayoade AA (2011) Length-weight relationship and diet of African Carp Labeo ogunensis (Boulenger, 1910) in Asejire Lake Southwestern Nigeria. Journal of Fisheries and Aquatic Science 6: 472-478.

24. Imam TS, Bala U, Balarabe ML, Oyeyi TI (2010) Length-weight relationship and condition factor of four fish species from Wasai Reservoir in Kano, Nigeria. African Journal of General Agriculture 6: 125-130.

25. Shinkafi BA, Argungu LA, Akanbi HS (2010) Food and feeding habits of catfish (Synodontis nigrita Cuvier and Valenciennes) in River Rima, Sokoto, Nigeria. Nigerian Journal of Basic and Applied Science 18: 304-307.

26. Ndimele PE, Kumolu-Johnson CA, Aladetohun NF, Ayorinde OA (2010) Lengthweight relationship, condition factor and dietary composition of Sarotherodon melanotheron, Ruppell, 1852 (Pisces: Cichlidae) in Ologe Lagoon, Lagos Nigeria. Agric Biol J N Am 1: 584-590.

27. Offem BO, Samsons YA, Omoniyi IT (2009) Trophic ecology of commercially important fishes in the Cross River, Nigeria. The Journal of Animal and Plant Sciences 19: 37-44.

28. Kalu KM, Umeham SN, Okereke F (2007) Length-weight relationship and condition factor of Clarias gariepinus and Tilapia zillii in Lake Alau and Monguno hatchery, Borno State, Nigeria. Animal Research International 4: 635-638.

29. Fafioye OO, Oluajo OA (2005) Length-weight relationships of five fish species in Epe Lagoon, Nigeria. Afr J Biotechnol 4: 749-751.

30. CBDA (1984) A Resettlement Plan for the Lake Alau Dam, Jere bowl scheme. Agricultural survey and background studies report submitted to Chad Basin Development Authority by Askonning Nig, Ltd. 89.

31. Wakil UB, Haruna AB, Mohammed GA, Ndirmbita WL, Yachilla BM, et al. (2014) Examinations of the stomach contents of two fish species (Clarias gariepinus and Oreochromis niloticus) in Lake Alau, North-Eastern Nigeria. Agriculture, Forestry and Fisheries 3: 405-409.

32. Reed WJ, Burchard AJ, Hopson J, Yaro I (1967) Fish and fisheries of Northern Nigeria. Ministry of Agriculture, Northern Nigeria.

33. Ricker WE (1973) Linear regressions in fisheries research. Journal of Fisheries Research Board, Canada, 30: 409-434.

34. Zar JH (1984) Statistical analysis, Prentice Hall, International London.

35. Zar JH (1999) Biostatistical analysis (4thedn). Pearson Education, Singapore.

36. Achakzai WM, Achakzai SWM, Baloch WA, Qambrani GR, Soomro AN (2014) Length-weight relationship and condition factor of tank goby Glossogobuis giuris (Hamilton and Buchannan, 1822) from Manchar Lake District Jamshoro, Sindh, Pakistan. Sindh Univ Res Jour (Sci Ser) 46: 213-216.

37. Kashyap A, Awasthi M, Serajuddin M (2014) Length-weight and length-length relationship of freshwater murrel, Channa punctatus (Bloch, 1793) sampled from river Gomti in Lucknow region (Uttar Pradesh). World J Fish \& Marine Sci 6: 336-339.

38. Lawal MO, Sangoleye OJ, Seriki BM (2010) Morphometry and diet of Chrysichthys. African Journal of Biotechnology 9: 7955-7960. 
Citation: Olanrewaju AN, Kareem OK, Nyaku RE, Tubo MT (2017) Length-Weight and Length-Length Relationships of Heterotis niloticus (Cuvier, 1829) and Raiamas senegalensis (Steindachner, 1870). J Aquac Res Development S2: 011. doi:10.4172/2155-9546.S2-011

Page 5 of 5

39. Le Cren ED (1951) The length-weight relationship and seasonal cycle in gonad weight and condition in the perch (Perca fluviatilis). J Anim Ecol 20: 201-219.

40. Abowei JFN, Ezekiel EN (2013) The length-weight relationship and condition factor of Chrysichthys nigrodigitatus (Lacepède, 1803) from Amassoma River flood plains. Sci Agri 3: 30-37.

41. Shafi S, Yousuf AR (2012) Length-weight relationship and condition factor of Schizothorax niger (Heckel, 1838) Misra from Dal lake, Kashmir. International Journal of Scientific and Research Publications 2: 1-3.

42. Adeyemi SO (2010) Length-weight, length-length relationship and condition factor of Synodontis resupinatus at Idah Area of River Niger, Nigeria. PAT 6: 85-90.

43. Adeyemi SO (2011) Fishery ecology of Gbedikere Lake, Kogi State, Nigeria Lambert Academic Publishing, USA.

44. APHA (American Public Health Association) (1995) Standard methods for the examination of water and wastewater (19thedn). OPH Washington D.C.

45. Lawal MO (2010) Nigrodigitatus (Lacépède) in Epe Lagoon, Nigeria. African Journal of Biotechnology 9: 7955-7960.

This article was originally published in a special issue, Current and Emerging Diseases/Disorders of Fish in Aquaculture handled by Editor(s). Prof. Patrick T.K. Woo, University of Guelph, Canada; Dr. Kenneth D. Cain, University of Idaho, USA. 